\title{
The typing of Staphylococcus epidermidis by a lectin-binding assay
}

\author{
J. O. JARL $\oslash V^{*} \dagger \ddagger$, J.-E. S. HANSEN $\dagger$, VIBEKE T. ROSDAHL $\ddagger$ and F. ESPERSEN§ \\ †Departments of Infectious Diseases and Clinical Microbiology, Hvidovre University Hospital, $\ddagger$ Division of \\ Preventive Microbiology, Statens Seruminstitut, and §Department of Clinical Microbiology, Rigshospitalet, \\ Copenhagen, Denmark
}

\begin{abstract}
Summary. A new typing method for Staphylococcus epidermidis was developed. Four biotinylated lectins - wheat germ agglutinin (WGA), soy bean agglutinin (SBA), lentil agglutinin (LCA) and Concanavalin A (ConA)-were added to immobilised whole cells of coagulase-negative staphylococci (CNS) in microtitration plates. The amount of bound lectin was measured by peroxidase-conjugated avidin followed by a peroxidase reaction. The method was compared to antibiotic-resistance analysis, phage typing, plasmid DNA profiles and slime production. A total of 113 isolates of CNS from 21 patients was investigated and 71 strains of CNS, including 64 strains of $S$. epidermidis, were detected if all typing methods were taken into consideration. If only one typing method was used the highest discriminatory power among the $S$. epidermidis isolates was obtained with the lectin-binding assay which allowed 49 different strains to be detected. If the lectin-binding assay was combined with plasmid-profile analysis, all 64 different strains could be identified. The typability of lectinbinding assay was $96.9 \%$ among the $S$. epidermidis isolates and 25 different lectin-binding patterns were established among the 64 strains. The highest number of strains belonging to one lectin-binding pattern was $13(20.3 \%)$. The assay was reproducible, easy to perform, relatively inexpensive and therefore applicable to large scale typing of $S$. epidermidis.
\end{abstract}

\section{Introduction}

Coagulase-negative staphylococci (CNS), predominantly Staphylococcus epidermidis, are normal inhabitants of the skin and mucous membranes and these organisms may cause infections in patients with compromised immunity including neonates, those with prosthetic valves, cerebrospinal fluid (CSF) shunts and intravenous devices, and in patients undergoing chronic ambulatory peritoneal dialysis. ${ }^{1-6}$ When CNS are isolated from blood cultures, it may be difficult to differentiate between true infection and contamination. ${ }^{2,3,5,7,8}$ The isolation of the same CNS strain on several occasions from the same patient suggests the presence of a true infection, and, with this in mind, various typing systems to identify and type CNS have been described. Among these, species identification, biotyping, plasmid DNA analysis with or without the application of restriction endonucleases, antibiograms and phage typing are the most widely used. ${ }^{1,3-10}$ However, the typability of CNS by means of phage typing is low, ${ }^{3,6,11}$ antibiograms and plasmid-DNA profile analysis are not always repro-

Received 16 April 1991; revised version accepted 1 Dec. 1991. * Present address for correspondence: Statens Seruminstitut, Division of Preventive Microbiology, 5 Artillerivej, DK 2300 Copenhagen S, Denmark. ducible and conclusive, ${ }^{3-5,10}$ and the applicability of plasmid analysis is limited as the method is timeconsuming and expensive.

Lectins are proteins or glycoproteins of nonimmune origin, which bind specifically to carbohydrate residues. ${ }^{12-16}$ Interactions between lectin-like structures on bacterial surfaces and their role in attachment to host cells have been studied. ${ }^{14,17}$ Bacterial surface components such as peptidoglycan, teichoic acid and lipoteichoic acid $^{18,19}$ contain many carbohydrate residues which might react with various lectins. Agglutination and gel-diffusion assays with lectins have been used to differentiate between Neisseria gonorrhoeae and other Neisseria species, ${ }^{20}$ and between coagulase-positive and coagulase-negative staphylococci ${ }^{21}$ lectins have also been used for epidemiological studies of Haemophilus ducreyi infections. ${ }^{22}$ Interactions between cell-wall components and lectins have been investigated by precipitation and gel-diffusion assays. ${ }^{23-25}$ However, these lectin-mediated agglutination and precipitation methods are probably not as sensitive as enzyme-linked assays (e.g., enzyme-linked immunosorbent assays, ELISA). The present study was undertaken to develop and evaluate a typing assay in which specific biotin-linked lectins were allowed to react with carbohydrates on the surface of CNS immobilised in microtitration plates. 
Table I. Biotinylated lectins used in the study

\begin{tabular}{lllcc}
\hline \multicolumn{1}{c}{ Lectin } & \multicolumn{1}{c}{ Specificity } & Inhibiting monosaccharide & Mol. wt & Biotinylation* \\
\hline Wheat germ (WGA) & N-linked, bisected complex type glycans & N-acetyl-D-glucosamine & $3.6 \times 10^{4}$ & $4 \cdot 5$ \\
Soy bean (SBA) & O-linked glycans & N-acetyl-D-galactosamine & $11 \times 10^{4}$ & 3 \\
Lentil (LCA) & N-linked, biantennary complex type glycans & $\alpha$-D-mannosyl & $4 \cdot 9 \times 10^{4}$ & $2-3$ \\
Concanavalin A (ConA) & N-linked, high mannose type glycans & $\alpha$-D-mannosyl & $10 \cdot 2 \times 10^{4}$ & $4-8$ \\
\hline
\end{tabular}

* Moles of biotin/mole of lectin.

\section{Materials and methods}

\section{Patients}

In total, 113 CNS isolates were cultured from 91 specimens from 21 patients. Underlying conditions included haematological malignancies, prosthetic valve endocarditis, intravascular and intraventricular shunt infections and prosthetic hip sepsis. The isolates originated from blood, bone biopsies, intravenous devices, foci in the oral cavity, cardiac valves, CSF, lung biopsy, pleural efflusion, an anal lesion and a cicatrice. The isolates were referred to the Staphylococcus Reference Laboratory, Statens Seruminstitut, for further investigations to evaluate possible CNS infections.

\section{Bacteria}

CNS were identified initially by morphology, Gram's stain, and negative reactions for coagulase production and clumping factor and then speciated by a modified Kloos and Schleifer scheme. ${ }^{9}$ The isolates were identified as $S$. epidermidis (105), S. hominis (3) and $S$. haemolyticus (1). Four isolates could not be identified to species level and were designated "uncharacterised". All bacteria were stored in oxbouillon with glycerol $10 \%$ at $-80^{\circ} \mathrm{C}$ until further investigation.

\section{Lectins}

For preliminary investigations, biotinylated lectins were kindly provided by Kem-en-Tec, Copenhagen, Denmark. The following biotinylated lectins were used in later experiments and purchased from Sigma Chemicals (St Louis, MO, USA): wheat-germ agglutinin (WGA), ${ }^{15,16}$ soy bean agglutinin (SBA), ${ }^{13,15,16}$ Lens culinaris agglutinin (LCA) ${ }^{12,15,16}$ and Concanavalin $\mathrm{A}(\mathrm{ConA}){ }^{12,15,26}$ The carbohydrate specificities and other characteristics of these lectins are shown in table I. Biotinylated lectins were used to increase the sensitivity. ${ }^{27}$ All lectins were dissolved in normal saline supplemented with $5 \mathrm{mM} \mathrm{NaN}_{3}$ to a concentration of $1 \mathrm{mg} / \mathrm{ml}$ and stored at $4^{\circ} \mathrm{C}$ until use.

\section{Lectin-binding assay}

Attachment of bacteria to the wells in microtitration plates was performed as previously described ${ }^{28}$ with the following modifications. Two or three colonies from a blood-agar plate were inoculated into $10 \mathrm{ml}$ of Mueller-Hinton broth, incubated for $18 \mathrm{~h}$ at $35^{\circ} \mathrm{C}$, harvested and washed three times $(1600 \mathrm{~g}, 10 \mathrm{~min})$ in phosphate-buffered saline (PBS), pH 7.38, and resuspended in PBS. Concentrations of bacteria from $2 \times 10^{5} \mathrm{cfu} / \mathrm{ml}$ to $10^{9} \mathrm{cfu} / \mathrm{ml}$ were tested. A bacterial suspension of $5 \times 10^{7} \mathrm{cfu} / \mathrm{ml}$ was the highest concentration which gave a sufficiently low background level and was chosen for further studies. Bacterial suspensions $(100 \mu \mathrm{l})$ were used to coat wells of 96-well, flat-bottomed microtitration plates (NUNC Immunoplate, Denmark). Glutaraldehyde $(200 \mu \mathrm{l}$; $0.0625 \% \mathrm{w} / \mathrm{v}$ ) was added to each well, and the plates were centrifuged at $2100 \mathrm{~g}$ for $15 \mathrm{~min}$. After aspiration, free binding sites were blocked with $200 \mu \mathrm{l}$ of blocking buffer (PBS, Tween $200.1 \%, 0.5 \mathrm{M} \mathrm{NaCl}$, $0.5 \mathrm{mM} \mathrm{MnCl}_{2}, 0.5 \mathrm{mM} \mathrm{CaCl}_{2}$ and $0.5 \mathrm{mM} \mathrm{MgCl}_{2}$ ) and plates were incubated at $22^{\circ} \mathrm{C}$ for $1 \mathrm{~h}$. Plates were washed three times in washing solution (PBS, $\mathrm{pH} 7.2$; Triton X $1001 \% \mathrm{w} / \mathrm{v}$ ) and stored at $4^{\circ} \mathrm{C}$ until used. Preliminary experiments demonstrated that plates could be stored for 1 week without altered activity.

Biotinylated lectins, WGA, SBA, LCA and ConA $(100 \mu \mathrm{l})$ were added to the bacteria-coated microtitration plates. In preliminary studies, six concentrations were tested (range 0.5-30 $\mu \mathrm{g} / \mathrm{ml}$ ), except for WGA for which 10 concentrations were tested (range $0.05-30 \mu \mathrm{g} / \mathrm{ml}$ ); blocking buffer was used as diluent. Incubation was performed for $0.5 \mathrm{~h}$ to $18 \mathrm{~h}$ at $22^{\circ} \mathrm{C}$, and for $0.5 \mathrm{~h}$ to $2 \mathrm{~h}$ at $30^{\circ} \mathrm{C}$ and $35^{\circ} \mathrm{C}$; an incubation period of $2 \mathrm{~h}$ at $22^{\circ} \mathrm{C}$ was found to be optimal and was used in the final method. The plates were then washed five times and incubated with $100 \mu \mathrm{l}$ of peroxidaseconjugated avidin (Dakopatts, Glostrup, Denmark) in blocking buffer for various periods $(5-60 \mathrm{~min})$ at six different concentrations (range 1 in 1000-1 in 20000); a concentration of 1 in 10000 incubated for $15 \mathrm{~min}$ at $22^{\circ} \mathrm{C}$ was judged to be optimal as this minimised background readings. The peroxidase reaction was performed with 1,2-phenylenediamine-dihydrochloride (Dakopatts) as chromogen, according to the manufacturers' instructions and the plates were then read at $492 \mathrm{~nm}$ (Intermed ImmunoReader NJ 200, Teknunc, Roskilde, Denmark). All tests were done in triplicate, and controls with and without bacteria and lectins were included in each plate. Intra-plate variation (i.e. variation of the same isolate after independent investigation in the same plate) and day-to- 
day variation were determined by investigating the same strains in different plates and on different days (table II). As an additional control, three of the $S$. epidermidis isolates representing different lectin-binding patterns (table III) were examined in all plates to evaluate variations in lectin activity.

The results are expressed as $1000 \times$ (mean OD valuebackground value). The ODs of the bacteria-free wells incubated with lectin-conjugated avidin were defined as the background. Results $<200$ were considered as negative test values.

\section{Inhibition studies}

The specificity of the lectin binding to two $S$. epidermidis strains was investigated by testing the following carbohydrates for their ability to inhibit binding: N-acetyl-D-glucosamine, D-glucose, Nacetyl-D-galactosamine, D-galactose, D-mannose and methyl-gluco-pyranoside, each at three concentrations $(0.01 \%, 0.1 \%$ and $1 \% \mathrm{w} / \mathrm{v})$.

\section{Antibiotic susceptibility testing}

Susceptibility tests were performed by the tabletdiffusion test with Rosco Neo-Sensitabs (Rosco Diagnostica, Taastrup, Denmark) ${ }^{29}$ on Danish bloodagar plates ${ }^{29}$ at $35^{\circ} \mathrm{C}$, except for methicillin which was examined on salt-agar $7.5 \%$ at $30^{\circ} \mathrm{C}$. The following antibiotics were tested: penicillin-G $(P)$, streptomycin $(S)$, tetracycline $(T)$, gentamicin $(G)$, erythromycin (E) and methicillin (M).

\section{Phage typing}

Phage typing was performed according to the method of Rosdahl et al. ${ }^{11}$ with the following phages: $15,27,28,28 \mathrm{~A}, 37,48,71,82,155,157 \mathrm{~A}, 165,275$, 275A, 456, 459, 471A, A6C, A9C, R6 and B1. More than two strong reaction differences between two isolates was regarded as indicating separate strains.

\section{Plasmid-DNA analysis}

Plasmid DNA analysis was performed as described by Rosdahl $^{30}$ with the modifications reported by Møller. $^{31}$

\section{Slime production}

Slime-producing CNS strains were identified by the tube method described by Christensen et al..$^{2}$ and graded as follows: a strong reaction with a confluent slime layer, grade 3 ; a positive reaction without a confluent layer, grade 2 ; a weak reaction, grade 1 ; and a negative reaction, grade 0 .

\section{Statistical analysis}

The analytical variation (intra-plate and day-to-day variation) of the lectin-binding assay was determined by the double determinations of strains. The following formula was used

$$
S D=\sqrt{\frac{\Sigma d^{2}}{2 n}}
$$

where SD is the standard deviation, $\Sigma \mathrm{d}^{2}$ is the sum of squared differences of double determinations of the same strain and $\mathrm{n}$ is the number of strains tested $(\mathrm{n}=$ 7-18). The strains selected for these determinations had responses that covered the range of responses for the individual lectins.

Isolates were considered to be different if their lectin values deviated more than the maximal variation with $95 \%$ confidence limits as calculated for the intraplate variations (table II); thus, variation $\times\left(\sqrt{ } 2 \times \mathrm{t}_{95 \%}\right)$, gave ratios of $1.22,1.66,1.52$ and 1.37 between values for WGA, SBA, LCA and ConA, respectively; ratios greater than these indicate non-identity between isolates examined in the same plates.

\section{Results}

Optimisation and analytical variation of the lectin-binding assay

Optimal concentrations of each of the lectins incubated at $22^{\circ} \mathrm{C}$ for $2 \mathrm{~h}$, and day-to-day and intra-plate variation are shown in table II. Variation in binding was observed for SBA and ConA with different supplies of the product. The stability of ConA in solution was rather low, particularly if stored for $>2$ months. Repeated subculturing up to 10 times did not alter the lectin-binding reactions of two strains of S. epidermidis.

\section{Inhibition studies}

The lectin-binding reactions were highly specific except for LCA. WGA was inhibited $90 \%$ by Nacetyl-D-glucosamine $1 \% \mathrm{w} / \mathrm{v}$. $\mathrm{N}$-acetyl-D-galactosamine $0.1 \% \mathrm{w} / \mathrm{v}$ and $\mathrm{D}$-glucose $1 \% \mathrm{w} / \mathrm{v}$ completely inhibited SBA. ConA was totally inhibited by Dmannose $0.1 \% \mathrm{w} / \mathrm{v}$ and methyl-gluco-pyranoside $0.1 \% \mathrm{w} / \mathrm{v}$ and $\mathrm{D}$-glucose $1 \% \mathrm{w} / \mathrm{v}$. Methyl-gluco-

Table II. Optimal lectin concentration and analytical variation for the lectin-binding assay determined by double determination of strains

\begin{tabular}{lccccc} 
Lectin & $\begin{array}{c}\text { Intra-plate } \\
\text { variation (\%) }\end{array}$ & $\mathrm{N}^{*}$ & $\begin{array}{c}\text { Day-to-day } \\
\text { variation (\%) }\end{array}$ & $\mathrm{N}^{*}$ & $\begin{array}{c}\text { Optimal } \\
\text { concentration } \\
(\mu \mathrm{g} / \mathrm{ml})\end{array}$ \\
\hline WGA & $7 \cdot 4$ & 18 & $18 \cdot 7$ & 14 & $0 \cdot 1$ \\
SBA & $22 \cdot 4$ & 18 & $29 \cdot 6$ & 11 & 10 \\
LCA & 17.0 & 18 & 32.0 & 7 & 6 \\
ConA & $12 \cdot 4$ & 18 & $31 \cdot 8$ & 14 & 6 \\
\hline
\end{tabular}

* N, number of strains included in the calculations. For the intraplate variations all examined strains were considered; for the dayto-day variations only strains with $O D$ values $>100$ were included. 
Table III. Lectin-binding patterns of 64 strains of $S$. epidermidis (primarily classified as "strains" by antibiograms, phage typing, plasmid profiles and lectin analysis)

\begin{tabular}{lc}
\hline $\begin{array}{l}\text { Lectin-binding pattern* } \\
\text { (WGA/SBA/LCA/ConA) }\end{array}$ & $\begin{array}{c}\text { Number of } \\
\text { strains }\end{array}$ \\
\hline$-/-/-/-$ & 2 \\
$-/-/-/ 200$ & 1 \\
$-/-/-/ 393$ & 3 \\
$314 /-/-/-$ & 1 \\
$493 /-/-/-$ & 2 \\
$1908 /-/-/-$ & 6 \\
$200 /-/-/ 393$ & 1 \\
$314 /-/-/ 772$ & 1 \\
$774 /-/-/ 772$ & 1 \\
$1215 /-/-/ 200$ & 1 \\
$1215 /-/-/ 393$ & 1 \\
$1215 /-/-/ 772$ & 2 \\
$1908 /-/-/ 200$ & 5 \\
$1908 /-/-/ 393$ & 13 \\
$1908 /-/-/ 772$ & 4 \\
$2995 /-/-/ 200$ & 1 \\
$2995 /-/-/ 393$ & 7 \\
$2995 /-/-/ 772$ & 5 \\
$-/ 739 /-/-$ & 1 \\
$-/ 739 /-/ 200$ & 1 \\
$774 / 384 /-/-$ & 1 \\
$1215 / 200 /-/ 393$ & 1 \\
$774 / 200 /-/ 1516$ & 1 \\
$2995 / 200 / 414 / 772$ & 1 \\
$2995 / 739 / 414 / 200$ & 1 \\
$1908 /-/-/ 200$ & 5 \\
& \\
\hline
\end{tabular}

* Values in the lectin patterns represent $\mathrm{OD}_{402} \times 1000$; values $<200$ are recorded as negative. Each strain is placed in the lectin pattern which approximated to the actual lectin value of that strain (see text for calculation of intervals between adjacent lectin-binding patterns).

pyranoside $1 \% \mathrm{w} / \mathrm{v}$ inhibited LCA but only by 50 $70 \%$ and there was no inhibition with D-glucose or Dmannose. For all the lectins, inhibition was not found with carbohydrates not specific for that lectin.

\section{Typing of isolates}

As patients were not epidemiologically related, isolates were evaluated from each patient separately and defined as different if they originated from different patients even if test results showed identity. In the lectin-binding assay, all strains from one patient were examined in the same set of microtitration plates and, therefore, evaluation of identity and non-identity between isolates in this assay is based on intra-plate variations.

If all the applied typing methods, except the slime test, were taken into consideration, it was possible to group the $113 \mathrm{CNS}$ isolates as 71 different strains of CNS, 64 of which were $S$. epidermidis. The slime test did not give any meaningful separation of strains, was difficult to read and was, therefore, omitted from further analysis. As subdivision of $S$. epidermidis isolates was the main purpose of the typing scheme, only these strains were analysed further.
Table IV. Typability of the 64 S. epidermidis isolates and number of different "strains" classified by the four typing methods alone and in different combinations

\begin{tabular}{lcc}
\hline Typing method & $\begin{array}{c}\text { Number (\%) of } \\
\text { strains typable }\end{array}$ & $\begin{array}{c}\text { Number of } \\
\text { strains classified }\end{array}$ \\
\hline Resistance pattern (RP) & $64(100)$ & 42 \\
Phage typing (PT) & $12(18 \cdot 8)$ & 11 \\
Plasmid profile (PP) & $56(87 \cdot 5)$ & 45 \\
Lectin-binding assay (LBA) & $62(96 \cdot 9)$ & 49 \\
RP+PT & $64(100)$ & 45 \\
RP+PP & $64(100)$ & 54 \\
RP+LBA & $64(100)$ & 59 \\
PT+PP & $59(93 \cdot 3)$ & 50 \\
PT+LBA & $62(96 \cdot 9)$ & 54 \\
PP+LBA & $64(100)$ & 64 \\
RP+PT+PP & $64(100)$ & 55 \\
RP+PT+LBA & $64(100)$ & 61 \\
RP+PP+LBA & $64(100)$ & 64 \\
PT+PP+LBA & $64(100)$ & 64 \\
RP+PT + PP+ + LBA & $64(100)$ & 64 \\
\end{tabular}

\section{Typability and discriminatory power of the} lectin-binding assay

Only two of the 64 S. epidermidis isolates did not react with any of the lectins, a typability of $96.9 \%$ with this method. The majority, $(56,87.5 \%)$, of these isolates reacted with WGA and ConA $(50,78 \cdot 1 \%)$ but only seven $(10.9 \%)$ and two $(3.1 \%)$ reacted with SBA and LCA, respectively. The $64 \mathrm{~S}$. epidermidis isolates could be grouped in 25 lectin-binding patterns (table III). These patterns were defined on the basis of dayto-day variations for the assay. The interval between adjacent values for the same lectin in table III is calculated as the maximal variation with $95 \%$ confidence limits [variation $\times\left(\sqrt{ } 2 \times t_{95 \%}\right)$ ], i.e., ratios between values were $1.57,1.92,2.07$ and 1.96 for WGA, SBA, LCA and ConA, respectively.

\section{Comparison between the lectin-binding assay and other typing methods}

To evaluate the clinical applicability of the lectinbinding assay compared to other typing methods, a comparison was performed on the $64 S$. epidermidis isolates which had represented a clinical problem in the 21 different patients.

The highest number of "strains" classified by a single typing system was 49 in the lectin-binding assay. If assays were combined, the lectin-binding assay combined with plasmid profiles distinguished between the highest number of different "strains" (64), and addition of resistance patterns and phage typing did not enhance discrimination further (table IV).

When applied to the isolates from each of the 21 patients, there was total agreement between the lectinbinding assay and all other typing methods in the discrimination of the isolates from 12 patients. In five patients, one or more differences were found between the methods and discrimination of strains was enhanced. The multiple isolates from four patients 
Table V. Typing results of 11 isolates of $S$. epidermidis from a patient with prosthetic valve endocarditis

\begin{tabular}{rllcl}
\hline \multicolumn{2}{c}{$\begin{array}{c}\text { Isolate } \\
\text { no. }\end{array}$ site } & $\begin{array}{c}\text { Resistance } \\
\text { pattern }\end{array}$ & $\begin{array}{c}\text { DNA-plasmid } \\
\text { profile }\end{array}$ & $\begin{array}{c}\text { Lectin } \\
\text { reactions } \dagger\end{array}$ \\
\hline 1 & Blood & PTM & $2 / 1 / 0^{*}$ & $1650 /-/-/ 1103 \ddagger$ \\
2 & Blood & PTM & $3 / 1 / 1$ & $1736 /-/-/ 1128 \ddagger$ \\
3 & Blood & PTM & $3 / 1 / 1$ & $1520 /-/-/ 1154 \ddagger$ \\
4 & Cardiac & PTM & $3 / 1 / 1$ & $1895 /-/-/ 1068 \ddagger$ \\
& valve & & & \\
5 & Cardiac & PTM & $3 / 1 / 1$ & $1416 /-/-/ 825 \ddagger$ \\
& valve & & & \\
6 & Blood & PGEM & $0 / 0 / 2$ & $370 /-/-/-$ \\
7 & Blood & PTM & $3 / 1 / 1$ & $346 /-/-/ 837$ \\
8 & Blood & PTGM & $2 / 1 / 1$ & $1995 /-/-/ 1176 \ddagger$ \\
9 & Blood & PTGM & $0 / 1 / 0$ & $1064 /-/-/ 989$ \\
10 & Blood & PTM & $3 / 1 / 1$ & $1735 /-/-/ 1113 \ddagger$ \\
11 & Blood & PGEM & $3 / 1 / 1$ & $1405 /-/-/ 236$ \\
& & & & \\
\hline
\end{tabular}

P, penicillin; $T$, tetracycline; $M$, methicillin; $G$, gentamicin; $E$, erythromycin.

* Small ( $\leqslant 3 \mathrm{MDA}) /$ intermediate ( 3 MDA < $10 \mathrm{MDA}$ )/large (> $10 \mathrm{MDA})$.

+ Mean $\mathrm{OD}_{492} \times 10^{3} ;$ WGA/SBA/LCA/ConA; - , reaction $<200$

‡ Isolates of same identity according to lectin reactions (based on intra-plate variation of the assay; see text).

All isolates were non-typable by phage typing.

offered particular problems and the details of one of these patients, a case of prosthetic valve endocarditis, are shown in table V. S. epidermidis isolates 2-5 and 10 from this patient were identical by all typing methods; isolates 1 and 8 had identical lectin-binding patterns but isolate 1 lacked one large and one small plasmid and isolate 8 the same small plasmid when compared to isolates $2-5$ and 10 . These seven isolates seemed closely similar and it was concluded that they comprised three closely similar strains, which possibly originated from the same clone. The remaining four isolates $(6,7,9$ and 11$)$ probably represented a further four different strains. Although isolates 7 and 11 had plasmid patterns identical with isolates $2-5$ and 10 , they had different lectin reactions and isolate 11 was resistant to erythromycin. Isolates 6 and 9 were different from the rest and from each other in both plasmid profile and lectin reactions.

\section{Discussion}

All the isolates in this study originated from clinical specimens from patients with a clinical history which made $S$. epidermidis infection a distinct possibility. It is of crucial importance to test a typing system on relevant clinical isolates as only such tests will evaluate the applicability of the typing system for epidemiological purposes in clinical microbiology.

Previously described methods for typing of CNS are mainly derived from methods primarily designed for the typing of other bacterial species. Phage typing of CNS suffers from low typability; ${ }^{11}$ in our study only $18.8 \%$ of $S$. epidermidis isolates were phage-typable. Plasmid-DNA profile analysis is not always conclusive $^{10}$ and day-to-day reproducibility is a major prob- lem; furthermore, the method is rather expensive and the number of isolates which can be examined daily is limited. Antibiotic resistance patterns are valuable but stability must be taken into consideration. ${ }^{5}$ Therefore, there is a need to develop other typing systems for CNS which can be used routinely in clinical microbiology laboratories. The lectin-binding assay fulfills these criteria; it is simple, inexpensive and reproducible, and results from different days are comparable by means of established lectin patterns. In this study, the typability of $S$. epidermidis isolates was high $(96.9 \%)$ and the discriminatory power was sufficient to distinguish individual strains. The highest number of strains found in one lectin pattern was $13(20.3 \%)$ and 25 different lectin patterns were observed. The lectin-binding assay clearly helped in both differentiating and enhancing the likelihood of identity between isolates from patients.

All isolates for comparison were examined in the same set of microtitration plates, so up to 20 isolates could be examined simultaneously. The lectin patterns, which were based on day-to-day assay variations, could be used in the daily routine to indicate isolates which should be re-examined in the same set of plates.

WGA and ConA were responsible for the high typability and discriminatory power of the assay, as $87.5 \%$ and $78.1 \%$ of the $S$. epidermidis strains reacted with WGA and ConA respectively. Only $10.9 \%$ of isolates reacted with SBA and only $3 \cdot 1 \%$ (two strains) reacted with LCA; these two strains were cultured from the same blood culture and had reactions to all the lectins but to different degrees (lectin patterns $2995 / 200 / 414 / 772$ and 2995/739/414/200; table III). WGA probably binds to $\mathrm{N}$-acetyl-D-glucosaminecontaining terminal oligosaccharides in the staphylococcal cell-wall and membrane ${ }^{18,19}$ Some strains bound WGA only poorly; this may be due to the existence of a capsular substance which masked the oligosaccharide ligands. The binding of SBA to the bacteria may be via cell-wall teichoic acid, which can have $\mathrm{N}$-acetyl-D-galactosamine as a component. ${ }^{18}$ Other cell-wall components, e.g., mannose polymers (high-mannose type), could contribute to ConA binding.

Interestingly, only two strains (see above) from one patient bound LCA indicating that biantennary complex type glycans are not normally present in the cell walls of $S$. epidermidis. The diversity of lectin-binding patterns suggests that the glycosylation of $S$. epidermidis surface components is as heterogeneous as glycosylation of mammalian cell-surfaces or glycoproteins. Two strains (3.1\%) of S. epidermidis (table III) did not react with any of the lectins in our study. This was not due to insufficient bacteria bound to the microtitration plates and might well be a result of masking by capsular material.

Lectin patterns could not be correlated with the number or size of plasmids, antibiotic resistance patterns or slime production. Therefore, the lectinbinding assay is a valuable independent typing method 
for $S$. epidermidis which can be combined with other methods. The most useful combination may be the lectin-binding assay and the plasmid-profile analysis. The criteria for identity between isolates should be evaluated carefully. Minor differences in plasmid profiles between two isolates combined with relevant differences in resistance patterns may not be a satisfactory criterion for non-identity, although such a criterion was used for the maximum strain differentiation in this study.

\section{References}

1. Baddour LM, Barker LP, Christensen GD, Parisi JT, Simpson WA. Phenotypic variations of Staphylococcus epidermidis in infection of transvenous endocardial pacemaker electrodes. J Clin Microbiol 1990; $28: 676-679$.

2. Christensen GD, Simpson WA, Bisno AL, Beachey EH. Adherence of slime-producing strains of Staphylococcus epidermidis to smooth surfaces. Infect Immun 1982; 37: 318-326.

3. Etienne J, Renaud F, Bes $M$ et al. Instability of characteristics amongst coagulase-negative staphylococci causing endocarditis. J Med Microbiol 1990; 32: 115-122.

4. Ludham HA, Noble WC, Marples RR, Phillips I. The evaluation of a typing scheme for coagulase negative staphylococci suitable for epidemiological studies. J Med Microbiol 1989; 30: 161-165.

5. Mickelsen PA, Plorde JJ, Gordon KP et al. Instability of antibiotic resistance in a strain of Staphylococcus epidermidis isolated from an outbreak of prosthetic valve endocarditis. J Infect Dis 1985; 152: 50-58.

6. Parisi JT. Coagulase-negative staphylococci and epidemiological typing of Staphylococcus epidermidis. Microbiol Rev $1985 ; 49: 126-139$.

7. Arpi M, Gahrn-Hansen B, Rosdahl VT. Contaminating coagulase-negative staphylococci isolated in a lysiscentrifugation (Isolator ${ }^{\star}$ ) blood culture system. APMIS 1988; 96: 611-617.

8. Hartstein AI, Valvano MA, Morthland VH, Fuchs PC, Potter SA, Crosa JH. Antimicrobic susceptibility and plasmid profile analysis as identity tests for multiple blood isolates of coagulase-negative staphylococci. J Clin Microbiol 1987; 25: 589-593.

9. Gahrn-Hansen B, Heltberg O, Rosdahl VT, Søgaard P. Evaluation of a conventional routine method for identification of clinical isolates of coagulase-negative Staphylococcus and Micrococcus species. Comparison with API-Staph and API-Staph-Ident. Acta Pathol Microbiol Immunol Scand Sect B 1987; 95: 283-292.

10. Parisi JT, Lampson BC, Hoover DL, Khan JA. Comparison of epidemiologic markers for Staphylococcus epidermidis. $J$ Clin Microbiol 1986; 24: 56-60.

11. Rosdahl VT, Gahrn-Hansen B, Møller JH, Kjældgaard P. Phage-typing of coagulase-negative staphylococci. Factors influencing typability. APMIS 1990; 98: 299-304.

12. Debray H, Montreuil J. Structural basis for the affinity of four insolubilized lectins with a specificity for alfa-D-mannose towards various glycopeptides with the $\mathrm{N}$-glycosamine linkage and related oligosaccharides. In: Bøg-Hansen TC (ed) Lectins, vol 1. New York, Walter de Gruyter Co. 1981 : 221-230.

13. Debray H, Pierce-Crétel A, Spik G, Montreuil J. Affinity of ten insolubilized lectins towards various glycopeptides with the $\mathrm{N}$-glycosamine linkage and related oligosaccharides. In Bøg-Hansen TC (ed) Lectins, vol 3. New York, Walter de Gruyter Co. 1983: 335-351

14. Eshdat, Y Sharon N. Recognitory bacterial surface lectins
Other lectins with different carbohydrate-binding properties may be used to enhance the discriminatory power in the typing system and this method may also be applied to the typing of bacteria other than $S$. epidermidis.

This work was supported by the Danish Medical Research Council (grant no 12-9510). We thank Mrs Jette Mondrup and Miss Aase V. Meyer for technical assistance.

which mediate its mannose-specific adherence to eukaryotic cells. Biol Cell 1984; 51: 259-266.

15. Goldstein IJ, Hayes CE. The lectins: carbohydrate-binding proteins of plants and animals. Adv Carbohydr Chem Biochem 1978; 35: 127-340.

16. Osawa T, Tsuji T. Fractionation and structural assessment of oligosaccharides and glycoproteins by use of immobilized lectins. Annu Rev Biochem 1987; 56: 21-42.

17. Firon N, Ofek, I, Sharon N. Carbohydrate specificity of the surface lectins of Escherichia coli, Klebsiella pneumoniae and Salmonella typhimurium. Carbohydr Res 1983; 120: 235-249.

18. Knox KW, Wicken AJ. Immunological properties of teichoic acids. Bacteriol Rev 1973; 37: 215-257.

19. Schleifer KH, Kandler O. Peptidoglycan types of bacterial cell walls and their taxonomic implications. Bacteriol Rev 1972; 36: 407-477.

20. Schaefer RL, Keller KF, Doyle RJ. Lectins in diagnostic microbiology: use of wheat germ agglutinin for laboratory identification of Neisseria gonorrhoeae. J Clin Microbiol 1979; 10: 669-672.

21. Davidson KS, Keller KF, Doyle RJ. Differentiation of coagulase-positive and coagulase-negative staphylococci by lectins and plant agglutinins. J Clin Microbiol 1982; 15: $547-553$.

22. Korting HC, Abeck D, Johnson AP, Ballard RC, TaylorRobinson D, Braun-Falco O. Lectin typing of Haemophilus ducreyi. Eur J Clin Microbiol Infect Dis 1988; 7: 678-680.

23. Lotan R, Sharon N, Mirelman D. Interaction of wheat-germ agglutinin with bacterial cells and cell-wall polymers. Eur $J$ Biochem 1975; 55: 257-262.

24. Reeder WJ, Ekstedt RD. Study of the interaction of concanavalin A with staphylococcal teichoic acids. J Immunol 1971; 106: 334-340.

25. Wagner $M$. Interaction of wheat-germ agglutinin with streptococci and streptococcal cell wall polymers. Immunobiol 1979 156: 57-64.

26. Kornfield R, Ferris C. Interaction of immunoglobulin glycopeptides with Concanavalin A. J Biol Chem 1975; 250 : 2614-2619.

27. Guesdon JL, Ternynck T, Avrameas S. The use of avidin-biotin interaction in immunoenzymatic techniques. $J$ Histochem Cytochem 1979; 27: 1131-1139.

28. Jarløv JO, Christensson B, Espersen F, Hertz JB, Hedström SÅ. Antibody response against whole Staphylococcus aureus in patients with staphylococcal septicaemia and endocarditis investigated by ELISA. Acta Pathol Microbiol Immunol Scand Sect B 1985; 93: 307-313.

29. Casals JB, Pedersen OG. Tablet sensitivity testing: a comparison of different methods. Acta Pathol Microbiol Immunol Scand Sect B 1972; 80: 806-816.

30. Rosdahl VT. Localisation of the penicillinase gene in naturally occurring Staphylococcus aureus strains. Acta Pathol Microbiol Immunol Sect $B$ 1985; 93: 383-388.

31. Møller JK. Drug resistance and plasmid profiles in Staphylococcus epidermidis in 1964 and 1986. J Hosp Infect 1988; 12: 19-27. 